\title{
ANALISIS EFEKTIVITAS PROJECT SCIENTIFIC DALAM MENILAI KEMAMPUAN PEDAGOGIK CALON GURU BIOLOGI
}

\author{
Cita Tresnawati, Yusuf Ibrahim, Mia Nurkanti. \\ Universitas Pasundan Bandung \\ Jln. Taman Sari no 6-8 Bandung 40116 \\ cita@unpas.ac.id, yusuf.ibrahim@unpas.ac.id,mia@unpas.com
}

\begin{abstract}
ABSTRAK
Penelitian ini bertujuan untuk menganalisis efektivitas kegiatan project scientific dalam menilai kemampuan pedagogik/mengajar mahasiswa calon guru biologi di 3 (tiga) Sekolah Menengah Atas di Bandung. Penelitian ini mengunakan metode penelitian deskriptif dengan pendekatan kuantitatif. Instrumen yang digunakan adalah : Lembar observasi yang menilai kemampuan pedagogik mahasiswa calon guru Biologi. Penelitian ini didasari dari pengembangan Model Lembar kerja Siswa berbasis project scientific yang di implementasikan di sekolah menengah atas oleh mahasiswa Praktek Pengenalan Lapangan (PPL). Sample pada penelitian ini adalah mahasiswa semester VII yang sedang melaksanakan Praktek Pengenalan Lapangan di sekolah menengah atas. Hasil penelitian menunjukkan kemampuan pedagogik selama kegiatan belajar mengajar pada kategori sangat baik dengan rerata nilai 3.80 hal ini menunjukkan mahasiswa calon guru biologi dapat melaksanakan tahapan pembelajaran sesuai dengan hirarki yang direncanakan. Adapun kemampuan pedagogik project scientific mahasiswa pada kategori baik dengan rerata nilai 2,80 berhasil mengarahkan siswa pada kerja ilmiah seperti kemampuan pemecahan permasalahan, perumusan masalah, hipotesis, langkah penyelidikan, fokus pengamatan, hasil pengamatan dan menyimpulkan.

Kata Kunci : Kemampuan Pedagogik, Kegiatan project scientific, Praktek Pengenalan Lapangan
\end{abstract}

\begin{abstract}
This study aimed to determine the effectiveness of scientific project in assessing prospective biology teacher's pedagogical competence. The study was conducted at three senior high schools in Bandung. It employed quantitative approach, specifically descriptive research method. The data was collected using observation sheets as research instruments. The participants of the study were students of Biology Education Department who were having internship program (PPL) at the research sites. The study shows that the participants' average score of pedagogical competence specifically in giving classroom instruction is 3.80 , which suggests that they are able to teach properly, i.e. in reference to thinking order hierarchy. While in conducting scientific project, the participant's average score is 2.80 ; in that the participants are able to think scientifically, starting from formulating problems, developing hypothesis, investigating the problems, observing, reporting the results of the observation, and making conclusion. Keywords: pedagogical competence, scientific project, Praktek Pengenalan Lapangan (PPL)
\end{abstract}

\section{PENDAHULUAN}

Peranan guru sangat kompleks, berkembang sesuai dengan perkembangan sejarah dan zaman dari masa ke masa, perubahan paradigma dan tata nilai pada abad ke-21, standar guru lebih ditekankan pada kemampuan profesionalnya. Guru yang efektif merupakan pribadi yang berkualitas dan dapat membangun hubungan yang baik dengan siswa, memahami pengetahuan dasar tentang belajar mengajar, dapat melaksanakan kegiatan pembelajaran dengan baik, mempunyai sikap dan keterampilan yang dibutuhkan untuk melakukan refleksi dan memecahkan masalah, serta meyakinkan bahwa belajar merupakan proses sepanjang hidup. Selain itu guru yang efektif dapat mengembangkan strategi, metode dan keterampilan untuk mencapai 
keberhasilan (Muh.Tawil dan Liliasari :2014).

Proses belajar mengajar mengandung kegiatan interaksi antara guru, siswa dan komunitas timbal balik yang berlangsung dalam situasi edukatif. Belajar tidak hanya merupakan suatu transfer pengetahuan saja dari guru kepada siswa tetapi siswa diberi persoalan-persoalan yang membutuhkan pencarian, pengamatan, percobaan, analisis, sintesis, perbandingan, pemikiran dan penyimpulan oleh siswa, agar siswa menemukan sendiri jawaban terhadap suatu konsep atau teori (Muh.Tawil dan Liliasari :2014).

Kemampuan calon guru dalam membuat perencanaan pelaksanaan pembelajaran (RPP) terutama kemampuan guru di dalam mengembangkan indikator termasuk dalam kompetensi pedagogik, yang merupakan kemampuan untuk merencanakan program belajar mengajar. Jadi perumusan indikator harus disesuaikan dengan kriteria yang telah ditentukan agar kegiatan belajar mengajar lebih efektif .

Namun ternyata dalam praktik mengajar sehari-hari banyak terjadi kesenjangan, ada sebagian guru yang tidak mempu menunjukkan profil guru yang baik sehingga keinginan anda maupun yang lainnya menjadi tidak terwujud. Alhasil banyak siswa yang kurang mampu menguasai bahan yang diajarkan guru dan guru pun kurang (tidak dapat) memahami semua jalan pikiran, perasa dan emosi siswanya (Hendra Surya : 2009).

Peraturan Pemerintah No 19 tahun 2005 tentang Standar Nasional yang terdiri atas 8 Standar Nasional Pendidikan, dan salah satu dari standar tersebut mengenai standar pendidik dan tenaga kependidikan yang menjelaskan bahwa guru profesional harus memiliki kualifikasi akademik, kompetensi sebagai agen pembelajaran, serta sertifikasi sebagai pendidik yang profesional.

Menurut Permendiknas Nomor 16 Tahun 2007 kompetensi pedagogik guru mata pelajaran terdapat 10 kompetensi inti yang harus dimiliki oleh guru diantaranya 1) Menguasai karakteristik peserta didik dari aspek fisik, moral, spiritual, sosial, kultural, emosional, dan intelektual. 2) Menguasai teori belajar dan prinsipprinsip pembelajaran yang mendidik. 3) Mengembangkan kurikulum yang terkait dengan mata pelajaran yang diampu. 4) Menyelenggarakan pembelajaran yang mendidik. 5) Memanfaatkan teknologi informasi dan komunikasi untuk kepentingan pembelajaran. 6). Memfasilitasi pengembangan potensi peserta didik untuk mengaktualisasikan berbagai potensi yang dimiliki. 7). Berkomunikasi secara efektif, empatik, dan santun dengan peserta didik. 8) Menyelenggarakan penilaian dan evaluasi proses dan hasil belajar. 9) Memanfaatkan hasil penilaian dan evaluasi untuk kepentingan pembelajaran. 10) Melakukan tindakan reflektif untuk peningkatan kualitas pembelajaran.

Beberapa

penelitian menunjukkan bahwa guru tidak memiliki kompetensi yang diperlukan untuk merealisasikan Instruksi berbasis penyelidikan ( Jiri Dostal et.al : 2014) tren menunjukkan bahwa instruksi berbasis penyelidikan didasarkan pada perubahan cara perolehan pengetahuan baru oleh murid yang ditransformasikan kepada siswa dengan bantuan didaktikal moderen, dengan menciptakan situasi yang tepat yang memungkinkan siswa untuk menemukan fakta-fakta baru dalam situasi belajar ( Jiri Dostal et.al : 2014). Hasil penelitian Yusuf Ibrahim dkk (2017) mengatakan Kemampuan mahasiswa dalam menyusun dan 
merancang Lembar Kerja Siswa (LKS) berbasis Project Scientific yang dikembangkan menjadi Lembar Kerja berbasis Problem Based Learning, Project Based Learning dan Inkuri di jaring melalui instrumen dalam bentuk penugasan terstruktur. Hasil analisis menunjukkan kemampuan mahsiswa dalam menyusun dan merancang Lembar Kerja Siswa (LKS) pada kategori kurang dengan rerata nilai $(2,00-2,60)$ teridentifikasi pada kesesuaian, prosedur praktikum dan Isi kegiatan praktikum.

Hasil penelitian Fransisca Sudargo dan Soesy Asiah S (2010) mengatakan bahwa Bentuk praktikum yang sesuai untuk meningkatkan kemampuan berpikir kritis, KPS (Keterampilan Proses Sains) dan hasil belajar siswa adalah praktikum dengan pendekatan inkuiri bebas, karena capaian hasilnya lebih baik dibandingkan dengan capaian hasil pada inkuiri terbimbing. Namun demikian capaian hasil ini tidak semata-mata karena penerapan pendekatan inkuiri dalam pembelajaran berbasis praktikum, karena faktor kemampuan siswa serta kondisi lingkungan belajar juga berperan dalam pencapaian hasil yang optimal.

Permasalahan

terkait kompetensi pedagogik dilapangan kenyataanya, tahapan proses pembelajaran masih menemui banyak masalah. Silabus dan RPP yang dimiliki guru pada umumnya disusun bersama di Kelompok Kerja Guru (KKG) atau di fotokopi dari sekolah atau lembaga lain dengan cara "copy file" atau rename tanpa adanya modifikasi dan revisi dalam rangka menyesuaikannya dengan peserta didik dan kondisi sekolah masing-masing. Bahkan sebagian guru menyusun RPP hanya untuk memenuhi kebutuhan administratif (bahan naik pangkat dan bahan usulan sertifikasi guru) bukan untuk pedoman dalam melakukan proses pembelajaran (Rifma : 2016). Penelitian ini peneliti ingin menganalisis dan mendeskripsikan kompetensi pedagogik mahasiswa calon guru biologi dalam menerapkan kegiatan project scientific disekolah pada pelaksanaan Program Pengenalan Lapangan (PPL).

\section{METODOLOGI}

Metode yang digunakan dalam penelitian ini adalah metode deskriptif dengan pendekatan kuantitatif. Penelitian ini mendeskripsikan kemampuan pedagogik selama kegiatan belajar mengajar dan selama kegiatan project scientific mahsiswa calon guru biologi pada saat Praktek Pengenalan Lapangan (PPL) di sekolah. Penelitian deskriptif (descriptive research) adalah suatu metode penelitian yang ditujukkan untuk menggambarkan fenomena-fenomena yang ada, yang berlangsung pada saat ini atau saat yang lampau (Furchan:2004). Penelitian dilaksanakan di Program Studi Pendidikan Biologi adapun Subjek dalam penelitian ini adalah mahasiswa calon guru Biologi yang sedang melaksanakan Praktek Pengenalan Lapang, di Lembaga Pendidikan Tenaga Kependidikan (LPTK) Swasta di Bandung.

Pada setiap langkah kegiatan dalam penelitian ini diperlukan instrumen-instrumen yang disusun sesuai kebutuhan. Instrumen dalam penelitian ini berupa:Instrumen yang menilai kemampuan pedagogik selama kebiatan belajar mengajar dan selama kegiatan project scientific.

\section{HASIL DAN PEMBAHASAN}

Data diperoleh dari hasil observasi yang dilakukan terhadap mahasiswa Pendidikan Biologi yang sedang melaksanakan Praktek Pengenalan Lapang (PPL) di sekolah 
yang menjadi mitra LPTK swasta di Bandung. Berikut adalah Hasil Analisis kemampuan pedagogik selama kegiatan belajar mengajar di sekolah. Data hasil observasi seperti ditunjukkan pada tabel 1. berikut ini :

Tabel 1. Kemampuan pedagogik selama kegiatan belajar mengajar

\begin{tabular}{|l|l|l|}
\hline No & \multicolumn{1}{|c|}{ Kategori penilaian } & Re \\
\hline 1 & Pra pembelajaran & \\
\hline 2 & Penguasaan materi & \\
\hline 3 & $\begin{array}{l}\text { Pendekatan/strategi/ } \\
\text { Model }\end{array}$ & \\
\hline 4 & Pemanfaatan sumber belajar & \\
\hline 4 & Memacu keaktifan siswa & \\
\hline 5 & Penggunaan bahasa & \\
\hline 6 & Kemampuan Menyimpulkan & \\
\hline 7 & $\begin{array}{l}\text { Kemampuan menutup } \\
\text { pembelajaran }\end{array}$ & \\
\hline
\end{tabular}

Berdasarkan tabel diatas kemampuan pedagogik mahasiswa selama kegiatan belajar mengajar secara keseluruhan pada kategori sangat baik dengan rerata nilai 3,80. Hasil observasi kemampuan mahasiswa pada pra pembelajaran menunjukkan kesiapan yang ditandai dengan menunjukkan perangkat pembelajaran seperti RPP (rencana pelaksanaan pembelajaran), bahan ajar, media pembelajaran dan lembar kerja project scientific yang akan digunakan.

Di awal pembelajaran mahasiswa calon guru mampu melakukan apersepsi dengan cukup baik ditandai dengan kemampuan menghubungkan materi pelajaran sebelumnya dengan materi yang akan disampaikan. Beberapa pertanyaan produktif mampu siswa jawab dengan cukup tepat. Kemampuan penguasaan materi pada kategori sangat baik hal ini terlihat pada kemampuan mahasiswa dalam mengaitkan materi dengan pengetahuan lain cukup relevan, jelas dan sesuai dengan hirarki belajar.
Kemampuan penalaran mahasiswa calon guru teridentifikasi cukup sistematis dan logis sesuai dengan tahapan dari model yang dikembangkan. Pendekatan saintifik terlihat pada saat kegiatan belajar mengajar menunjukkan mahasiswa mampu menyusun dan melaksanakan langkah-langkah pembelajaran sesuai Rectartgamilai sintak/tałKpitteria moel pemblelajaran yang disemglangledian.

3,30 Efektivitas Sghgut blain siswa

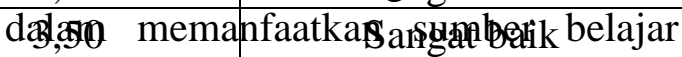
teridentifikasi guru mampu

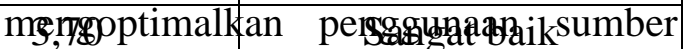
bejajor sehingga sktigdiasaikproject sçég6ific mampu megnkbangkitkan sejuygh potensi yangarfindtilik siswa. Kȩ,gompuan guru dalambamengarahkan kegiatan mampu memicu keaktifan siswa yang ditandai dengan perolehan nilai rerata siswa 3,40. Penggunaan bahasa, kemamampuan menyimpulkan dan kemampuan menutup pelajaran menunjukkan kemapuan1isan yang jelas, baik dan benar, mampu mnghubungkan antara konsep dengan kegiatan project scientific disertai dengan temuan konsep yang cukup memadai.

Kompetensi pedagogik adalah kemampuan guru mengelola pembelajaran peserta didik (Rifma : 2016). Kurikulum 2013 menekankan pada dimensi pedagogik modern dalam pembelajaran, yaitu menggunakan pendekatan ilmiah. Pendekatan ilmiah (scientific appoach) dalam pembelajaran sebagaimana dimaksud meliputi mengamati, menanya, mencoba, mengolah, menyajikan, menyimpulkan, dan mencipta untuk semua mata pelajaran. Untuk mata pelajaran, materi, atau situasi tertentu, sangat mungkin pendekatan ilmiah ini tidak selalu tepat diaplikasikan secara prosedural. Pada kondisi seperti ini, tentu saja proses pembelajaran harus tetap menerapkan nilai-nilai atau sifat- 
sifat ilmiah dan menghindari nilai-nilai atau sifat-sifat nonilmiah (Depdiknas, 2013).

Berdasarkan data yang diperoleh dalam menilai kemampuan pedagogik aktivitas project scientific seperti tertera pada tabel 2 . berikut ini

Tabel 2. Kemampuan pedagogik Project scientific

\begin{tabular}{llcc}
\hline No & $\begin{array}{c}\text { Kategori } \\
\text { penilaian }\end{array}$ & $\begin{array}{c}\text { Rerata } \\
\text { nilai }\end{array}$ & Kriteria \\
\hline 1 & $\begin{array}{l}\text { Kemampuan } \\
\text { mengarahkan } \\
\text { permasalahan }\end{array}$ & 3,30 & $\begin{array}{c}\text { Sangat } \\
\text { baik }\end{array}$ \\
\hline 2 & $\begin{array}{l}\text { kemampuan } \\
\text { mengarahkan } \\
\text { perumusan } \\
\text { masalah }\end{array}$ & 3,40 & $\begin{array}{c}\text { Sangat } \\
\text { baik }\end{array}$ \\
\hline 3 & $\begin{array}{l}\text { Kemampuan } \\
\text { mengarahkan } \\
\text { hipotesis }\end{array}$ & 3,50 & $\begin{array}{c}\text { Sangat } \\
\text { baik }\end{array}$ \\
\hline 4 & $\begin{array}{l}\text { kemampuan } \\
\text { mengarahkan } \\
\text { langkah } \\
\text { penyelidikan }\end{array}$ & 3,20 & $\begin{array}{c}\text { Sangat } \\
\text { baik }\end{array}$ \\
\hline 5 & $\begin{array}{l}\text { kemampuan } \\
\text { mengarahkan } \\
\text { fokus } \\
\text { pengamatan }\end{array}$ & 2,00 & Cukup \\
\hline 6 & $\begin{array}{l}\text { kemampuan } \\
\text { mengarahkan } \\
\text { hasil pengamatan }\end{array}$ & & \\
\hline 7 & $\begin{array}{l}\text { kemampuan } \\
\text { mengarahkan } \\
\text { fokus kesimpulan }\end{array}$ & 2,70 & Baik \\
\hline & & & Cukup \\
& & & \\
\hline & & & \\
\hline & & & \\
\hline
\end{tabular}

\section{Berdasarkan tabel diatas}

kemampuan mahasiswa secara keseluruhan menunjukkan kategori baik pada rerata nilai 2,80 dalam mengarahkan siswa pada kegiatan berbasis project scientific. Kemampuan yang dinilai diantaranya kemampuan mengarahkan permasalahan, perumusan masalah, hipotesis, langkah penyelidikan, fokus pengamatan, hasil pengamatan dan kesimpulan. Kemampuan mahasiswa calon guru yang termati pada saat observasi menunjukkan kemampuan mahasiswa cukup siap dalam melaksankan pembelajaran dengan mengarahkan siswa pada tahapan dan langkahlangkah pembelajaran saintifik.

Temuan di lapangan menunjukkan kompetensi pedagogik mahasiswa calon guru masih harus di tingkatkan lagi pada persiapan pra pembelajaran terutama dalam menyiapkan alat dan bahan untuk kegiatan project scientific. Beberapa kegiatan mahasiswa terkait penguasaan kelas dan penanganan siswa masih menunjukkan kategori kurang hal ini dikarenakan pengalaman dalam mengajar belum memadai.

Kendala yang dihadapai mahasiswa calon guru dalam mengimplementasikan kegiatan berbasis project scientific tampaknya pada persiapan yang kurang matang, sehingga terlihat di awal pra pembelajaran sedikit kaku. hard skill yang menunjang keterampilan di lapangan, khususnya mahsiswa calon guru biologi dalam menyiapkan kegiatan praktikum mutlak diperlukan. Kompetensi pedagogik diperlukan bagi calon guru diawali dengan mempersiapkan prangkat pembelajaran seperti RPP, Bahan Ajar, Media Pembelajaran, Lembar Kerja Peserta Didik, sampai merencanakan metode, strategi dan pendekatan apa yang cocok an sesuai dengan karakteristik peserta didik.

Analisis menunjukkan kendala yang dihadapi mahasiswa tampaknya pada kemampuan menghubungkan dan merangkai tahapan demi tahapan kegiatan. berdasarkan telaah dilapangan banyak siswa yang terlihat sedikit kebingungan dengan instruksi /petunjuk yang diberikan oleh mahsiswa calon guru hal ini dikarenakan siswa belum terbiasa dengan instruksi/ petunjuk kegiatan berbasis project scientifi, walau akhirnya siswa mampu menyesuaikan dengan instruksinya, mampu memahami dan menganalisis kegiatan yang sudah dilakukan. 
Analisis efektifitas sikap siswa selama pembelajaran menunjukkan antusias, aktif dan kreative, walaupun diawal pembelajaran telihat sedikit bingung terhadap instruksi yang diberikan. Kegiatan praktikum berlangsung tertib dan lancar, tahapan project scientific yang dilaksanakan berlangsung sistematis. Respon siswa cepat sehingga kegiatan praktikum berjalan lancar sesuai dengan tahapan dan instruksi pada lembar kerja siswa. Kemampuan mahasiswa calon guru cukup kompeten dalam memberikan arahan dan pengantar kegiatan dapat berlangsung dengan baik. Penggunaan project sacientific efektif merekonstruksi kesalahan konsep dan membangun konsep baru berdasarkan pengalaman langsung yang di kelas. Perkembangan daya nalar dan daya pikir dari kegiatan yang dikembangkan mampu mengembangkan kemampuan berpikir kritis siswa.

Kemampuan pedagogik mahasiswa calon guru dalam mengarahkan siswa pada proses penyelidikan berbasis project scientific efektif menilai kemampuan pedagogik mahasiswa calon guru biologi.

\section{KESIMPUL AN}

Kemampuan pedagogik kegiatan belajar mengajar mahsiswa calon guru Biologi sangat baik dengan rerata nilai 3.80 hal ini menunjukkan mahasiswa calon guru biologi dapat melaksanakan tahapan pembelajaran sesuai dengan hirarki yang telah direncanakan pada Rencana Pelaksanaan Pembelajaran (RPP). Pada beberapa bagian dari kemampuan pedagogik mahasiswa calon guru masih perlu ditingkatkan lagi seperti persiapan sebelum kegiatan belajar mengajar, penguasaan kelas dan siswa serta alokasi waktu pada saat kegiatan belajar mengajar berlangsung.

Adapun kemampuan pedagogik project scientific mahasiswa pada kategori baik dengan rerata nilai 2,80 berhasil mengarahkan siswa pada kerja ilmiah seperti kemampuan pemecahan permasalahan, perumusan masalah, hipotesis, langkah penyelidikan, fokus pengamatan, hasil pengamatan dan menyimpulkan. Hal tersebut menunjukkan kemampuan mahasiswa dalam mengarahkan aktivitas siswa berbasis project scientific cukup berhasil mengarahkan siswa pada kemampuan bernalar, walaupun pada beberapa bagian pada masih perlu untuk ditingkatkan lagi.

\section{DAFTAR PUSTAKA}

Depdiknas. (2013) Diklat Guru Dalam Rangka Implementasi Kurikulum 2013 Mata Jenjang: SD/SMP/SMA Konsep Pendekatan Scientific Jakarta: Departemen Pendidikan Nasional.

Furchan A. (2004). Pengantar Penelitian dalam Pendidikan. Yogyakarta: Pustaka Pelajar Offset.

Fransisca Sudargo, Soesy Asiah S. (2010). Kemampuan Pedagogik Calon Guru Dalam Meningkatkan Kemampuan Berpikir Kritis Dan Keterampilan Proses Siswa Melalui Pembelajaran Berbasis Praktikum Jurusan Pendidikan Biologi FPMIPA, Universitas Pendidikan Indonesia Jurnal Pengajaran MIPA, Volume 15, Nomor 1, hlm. 4-12

Hendra Surya. (2009). Menjadi Manusia Pembelajar. Jakarta : PT Elex Media Komputindo.

Ibrahim, Y. (2017). Pengembangan Model Lks Berbasis Project Scientific Untuk Meningkatkan Mutu Calon Guru Ipa Dalam Mengimplementasikan Kurikulum 
2013. Tekno Efisiensi Vol.2 No. 1 April 2017

Jiri Dostála, Milan Klement. (2014). Inquiry-Based Instruction And Relating Appeals Of Pedagogical Theories And Practices Published by Elsevier Ltd.
Rifma Dr. M.Pd. 2016. Optimalisasi Pembinaan Kompetensi Pedagogik Guru. Jakarta kencana Tawil, Muh dan Lilisari (2014). Keterampilan-Keterampilan Sains dan Implementasinya dalam Pembelajaran IPA. Makasar: Badan Penerbit UNM 